\title{
Teacher-Trainee Preparedness on Integration of ICT for Instruction in Selected Public Teacher Training Colleges in North Rift, Kenya
}

\author{
Kosgei Joan Jepchirchir (M.Phil) \\ Moi University, School of Education, Eldoret, Kenya \\ Katam Joseph Kipsaina (PhD) \\ Ministry of Public Service, Youth and Gender Affairs, Kapenguria, Kenya \\ Kemboi Mary Boit (PhD) \\ Moi University, School of Education, Eldoret, Kenya
}

\begin{abstract}
ICT is a very a very powerful medium of instruction in contemporary pedagogical processes. The aim of this study was to investigate teacher-trainee preparedness on the integration of ICT for learning in selected public teacher training colleges in North Rift, Kenya. The specific objectives were; to find out Teacher-Trainee planning process for use of ICT in teaching, determine teacher-trainee perception on integration of ICT in teaching and learning and to assess the teacher trainees' use of e-materials during learning process. The study was guided by Davis' Technology Acceptance Model (TAM). Descriptive research design and mixed method approach was used in this study. This study used questionnaires, document analysis and observation as instruments of collecting data. Slovin's formula was used to obtain a sample of 352 respondents from a target population of 2946 respondents. Purposive sampling was used to select three colleges and $2^{\text {nd }}$ year students. Proportionate simple random sampling technique was used to select teacher trainees from the cohort of the $2^{\text {nd }}$ year students. The questionnaire was face validated by education experts while the reliability was established by piloting the research instruments through test re-retest method. A Pearson Product Moment Correlation reliability coefficient of 0.8 was obtained indicating that the instrument was reliable. Descriptive statistics was used to analyze the data obtained and results presented in frequencies and percentages. The study findings showed that majority of the teacher trainees used ICT in searching teaching and learning materials. Majority of teacher trainees believed that ICT helped in lesson preparation. Majority of the teacher trainees believed that they updated content of their subject areas through the internet. It also emerged that majority of the teacher-trainees believed that ICT had positive effect on the quality of teaching and learning. Majority of the teacher trainees believed that ICT could enhance students' participation and feedback to teacher. Teacher-trainees occasionally used ICT applications during learning process. It was therefore concluded that teacher trainees needed basic skills in computer applications and that computer equipments be availed to all students for use in teaching and learning process. It was recommended that ICT be integrated into teacher education programmes to ensure adequate preparedness for classroom instruction.
\end{abstract}

Keywords: Teacher-trainee, preparedness, integration, ICT applications

\section{Background of the Study}

Learning is evolving from the traditional face-to-face-learning to adoption of ICT in instruction. Greater information access; greater communication; synchronous and asynchronous learning; increased cooperation and collaboration, cost-effectiveness and pedagogical improvement (Sife, Lwoga, \& Sanga, 2007)) have driven the institutions to adopt and incorporate ICT in 
teaching and learning. Pedagogical improvement through simulations, virtual experiences, and graphic representations have led both teachers and learners to choose more appropriate applications which are flexible in time, in place, personalized, reusable, adapted to specific domains and more cost-efficient (Sife et al., 2007).

Dawes (2001) is of the view that new technologies have the potential to support education across the curriculum and provide opportunities for effective communication between teachers and students in ways that have not been possible before. ICT in education has the potential to be influential in bringing about changes in ways of teaching. However, this potential may not easily be realized, as Dawes (2001) observed that problems often arise when teachers are expected to implement changes.

The effective integration of ICT into the education system's curriculum is a complex process. This process involves not only technology but also curriculum and pedagogy, institutional readiness, teacher competencies, and long-term financing, among others (Tinio, 2003). Today, most countries around the world are focusing on approaches to integrate ICT into learning and teaching so as to improve the quality of education by emphasizing such skills as critical thinking, decision-making and handling of dynamic situations, working in groups, or communicating effectively (Anderson \& Weert, 2002). Successful integration of ICT in the teaching-learning process, among other things, is dependent on the preparation of teacher (Mwalongo, 2011).

Mikre (2011) acceded that in recent years however, there has been a growing interest to know how computers and internet can best utilized to improve effectiveness and efficiency of education at all levels and in both formal and non- formal settings. As there is a shift of theories explaining learning processes, ICTs become handmaiden for learning activities. Voogt's (2003) description on the major roles, distinguished ICTs as an object for study, an aspect of a discipline or a profession, and a medium of instruction. As a medium of instruction, ICTs fit to realize and implement the emerging pedagogy of constructivism (Davis, 1997; Office of Technology Assessment, 1995; Panel on Educational Technology, 1997; Watson, 1996) in Voogt (2003). Moreover, Voogt (2003) differentiated between traditional learning setting and constructivist approaches. The former considers learning as transmission of knowledge to students, which is the sole responsibility of the teacher. On the other hand, the constructivist approach considers learning as authentic and learner centred. ICT, the computer for example is a great help in the constructivist approach, where one can design simulated and individualized learning environments to students.

\section{Objectives of the Study}

1. To find out teachers-trainee planning process for use of ICT for instruction in North Rift Teacher Training Colleges.

2. To determine teacher-trainee perception on integration of ICT for instruction and learning in North Rift Teacher Training Colleges.

3. To assess the teacher trainees use of e-materials during learning process in North Rift Teacher Training Colleges.

\section{Theoretical Frame Work}

The study adopted Davis' Technology Acceptance Model (TAM) (1989). Davis, Bagozzi and Warshaw (1989) developed a theory of 'action relating to reasons' (technology acceptance model) based on the work of Fishbein and Ajzen (in Davis et al, 1989) to investigate why some people use computers and their attitudes towards them. TAM posits that perceived usefulness 
and perceived ease of use determine an individual's intention to use a system with intention to use serving as a mediator of actual system use. Perceived usefulness is also seen as being directly impacted by perceived ease of use. In this study, perceived ease of use and perceived usefulness are believed to affect preparedness of teacher-trainees in the use of ICT. Thong, Hong, and Tam (2002) identified relevance, system visibility, and system accessibility as organizational context variables. They reported that the organizational context affects both perceived usefulness and perceived ease of use of ICT materials. Lin and Lu (2000) similarly reported that higher information accessibility brings about higher use of information and higher perception of ease of use.

In addition, knowing teacher trainees' intentions and understanding the factors that influence their beliefs about ICT integration can help academic administrators and managers to create mechanisms for attracting more students to adopt this learning environment (Grandon, Alshare, \& Kwan, 2005). This study investigated teacher-trainee preparedness on integration of ICT for instruction which could be influenced by their perception towards integration of ICT.

\section{Conceptual Framework}

The study conceptualized; Teachers-Trainee preparedness on integration of ICTs in the classroom, ICT influence to Teacher-Trainee in classroom, and level of teacher-trainee in the use of ICT in classroom as independent variables while adoption of ICT in classroom learning was the dependent variable as presented in Figure 1. 


\section{Independent variable}

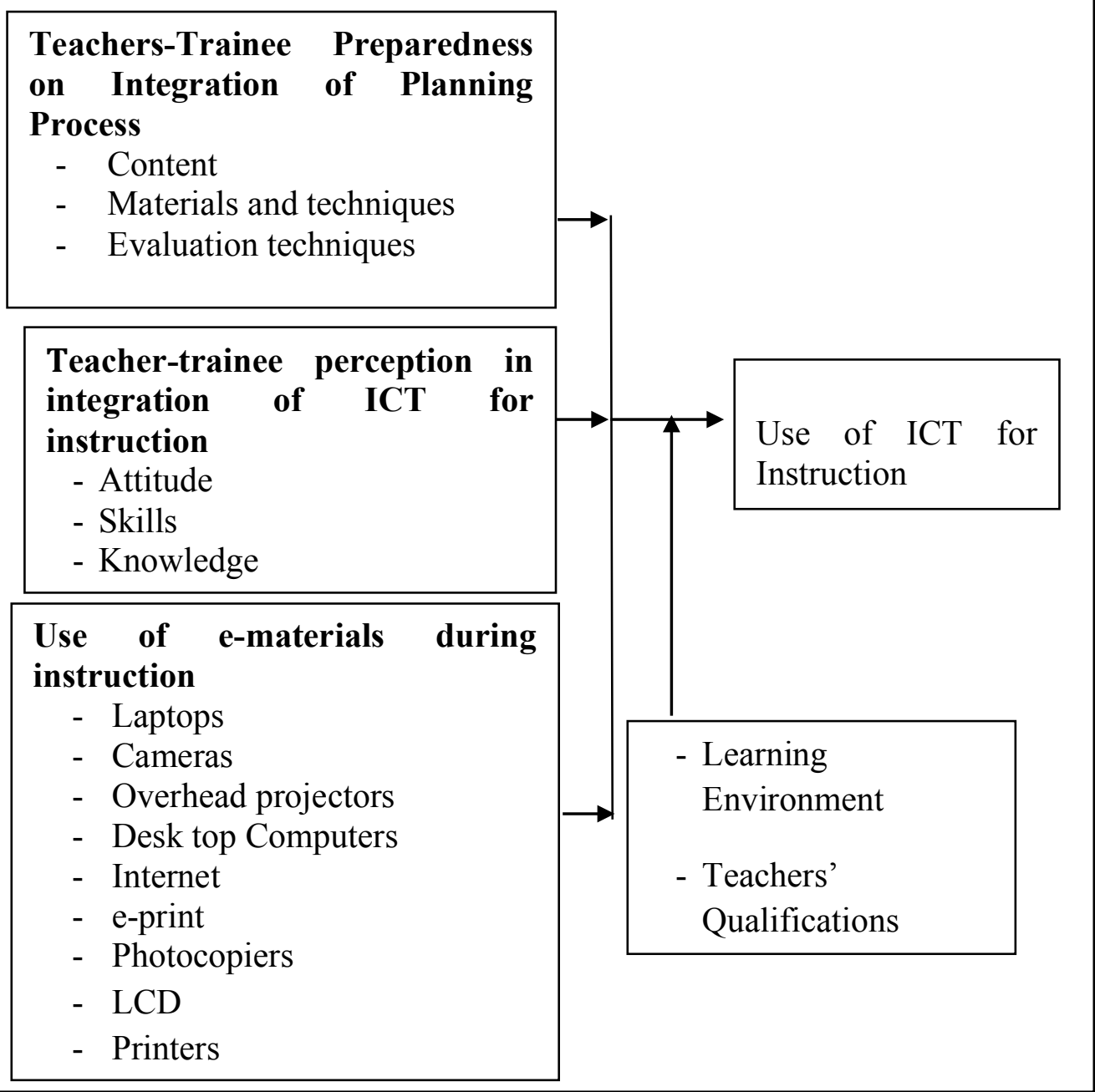

Figure1: Conceptual Framework Source: Researchers

\section{METHODOLOGY}

The study adopted descriptive survey research design. Descriptive survey design enables the researcher to describe the state of affairs as it is and reports the findings (Kothari, 2008). According to Kothari (2009), such design is efficient method of collecting descriptive data regarding the characteristics of the populations, justify current conditions and practices. The study aimed at collecting information from teacher trainees on preparedness of ICT for instruction. The study also used mixed methods approach (Teddlie, \& Tashakori 2009) which is a procedure for collecting and analyzing both quantitative and qualitative data. The blending of qualitative and quantitative methods in this study neutralizes bias, seeks convergence of results and produces final product which highlights the significant contribution of both approaches, where both, therefore used numeric and word data easily. Further, the researcher adopted a mixed methods approach as it provides the opportunity for presenting a greater diversity of divergent views (Creswell, 2009). This study focused on establishing the teachertrainee preparedness for use of ICT in instructions in selected public teachers colleges in North Rift. 
To obtain a representative sample, Slovin's formula was used:

Where;

$$
\mathrm{n}=\mathrm{N} /\left(1+\mathrm{Ne}^{\wedge} 2\right)
$$

$\mathrm{N}=$ population

$\mathrm{n}=$ Sample size

$\mathrm{e}=$ margins of error $(\mathrm{e}=0.05)$

Using Slovin's formula a sample size of 352 respondents was obtained from a target population of 2946 which is equivalent to $11.9 \%$.

Various sampling techniques were employed in order to come up with a representative sample for the study. Purposive sampling was used to select students from 3 teacher training colleges to participate in the study. After obtaining the 3 colleges, second year students were further selected purposively. Proportionate sampling technique was used to select students from each college. Table 1 presents the sample size of the population.

Table 1: Sample Size

\begin{tabular}{|l|l|c|c|c|}
\hline Institution & County & Population & Sample size & Percentage \\
\hline $\mathrm{A}$ & Nandi & 1200 & 143 & $11.9 \%$ \\
\hline $\mathrm{B}$ & $\begin{array}{l}\text { Elgeyo } \\
\text { Marakwet }\end{array}$ & 900 & 108 & $12.0 \%$ \\
\hline $\mathrm{C}$ & Baringo & 846 & 101 & $11.9 \%$ \\
\hline Total & & 2946 & 352 & $11.9 \%$ \\
\hline
\end{tabular}

\section{Source: Field Data}

Questionnaires, observation schedule and document analysis were used to collect data in this study. Structured questionnaire was the main instrument of collecting data. Using questionnaire helped to get information that is collected from large sample and diverse regions (Kothari, 2009). In each of the items in the questionnaire, respondents were required to rate each item. The questionnaire had four sections with section one covering the demographic description of participants involved in the study. Section two covered Teachers-Trainee planning process for use ICT in instruction while section three dealt with teacher-trainee perception on integration of ICT in instruction training colleges. The last section covered the teacher trainees' use of e-materials during instructional process.

Observation is a way of gathering data by watching behavior, events, or noting physical characteristics in their natural setting. In this study observation was used to collect data on how teachers used e-materials during learning process thus assisted in achieving the third objective.

The content of documents can be employed in systematic ways which looks at patterns and themes related to the research questions (Kothari, 2009). Therefore, the information obtained was further supplemented with data from document analysis and archives. The documents analyzed included records of purchased e-materials and log books for borrowed e-materials from the learning resource centre.

\section{FINDINGS AND DISCUSSION}

\section{Teacher-Trainee Planning Process of ICT for Instruction}

The first objective of this study was to find out Teachers-Trainee planning process for Instruction. To achieve this, the respondents were requested to rate their level of agreement 
Jepchirchir, K. J., Kipsaina, K. J., \& Boit, K. M. (2017) Teacher-Trainee Preparedness on Integration of ICT for Instruction in Selected Public Teacher Training Colleges in North Rift, Kenya. Advances in Social Sciences Research Journal, 4(5) 29-43

on five Likert scale questions on Teachers-Trainee planning process for use of ICT in teaching.

The results are presented in Table 2 .

Table 2: Teachers-Trainee Planning Process for Use of ICT in Instruction

\begin{tabular}{|c|c|c|c|c|c|c|c|c|c|c|}
\hline \multirow[t]{2}{*}{ Statement } & \multicolumn{2}{|c|}{ SD } & \multicolumn{2}{|c|}{$\mathrm{D}$} & \multicolumn{2}{|c|}{ UD } & \multicolumn{2}{|c|}{$\mathrm{A}$} & \multicolumn{2}{|c|}{ SA } \\
\hline & $\mathrm{F}$ & $\%$ & $\mathrm{~F}$ & $\%$ & $\mathrm{~F}$ & $\%$ & $\mathrm{~F}$ & $\%$ & $\mathrm{~F}$ & $\%$ \\
\hline \multicolumn{11}{|l|}{ Content } \\
\hline $\begin{array}{l}\text { I use ICT in searching teaching and } \\
\text { learning materials }\end{array}$ & 28 & 8.5 & 32 & 9.8 & 7 & 2.1 & 134 & 40.9 & 127 & 38.7 \\
\hline $\begin{array}{l}\text { It helps in lesson preparation and } \\
\text { preparation of notes }\end{array}$ & 0 & 0.00 & 39 & 11.9 & 26 & 7.9 & 164 & 50.0 & 99 & 30.2 \\
\hline $\begin{array}{l}\text { Through using teaching media it } \\
\text { help (s) clarification of the } \\
\text { concepts, and activeness of pupil } \\
\text { (s) in learning }\end{array}$ & 3 & .9 & 25 & 7.6 & 69 & 21.0 & 114 & 34.8 & 117 & 35.7 \\
\hline $\begin{array}{l}\text { I Search for materials through } \\
\text { internet so as to keep myself } \\
\text { update and increase my confidence } \\
\text { and competence in my subject of } \\
\text { specialization }\end{array}$ & 2 & .6 & 27 & 8.2 & 5 & 1.5 & 132 & 40.2 & 162 & 49.4 \\
\hline \multicolumn{11}{|l|}{ Materials and Techniques } \\
\hline $\begin{array}{l}\text { I can use instructional technologies } \\
\text { in class activities more effectively } \\
\text { day by day }\end{array}$ & 43 & 13.1 & 71 & 21.6 & 14 & 4.3 & 189 & 57.6 & 11 & 3.4 \\
\hline $\begin{array}{l}\text { Using graphics makes learning real } \\
\text { and enjoyable }\end{array}$ & 6 & 1.8 & 64 & 19.5 & 7 & 2.1 & 126 & 38.4 & 125 & 38.1 \\
\hline $\begin{array}{l}\text { Getting information and research } \\
\text { about best practices for teaching }\end{array}$ & 10 & 3.0 & 23 & 7.0 & 31 & 9.5 & 152 & 46.3 & 112 & 34.1 \\
\hline \multicolumn{11}{|l|}{ Evaluation } \\
\hline $\begin{array}{l}\text { Use of ICT makes it easier to } \\
\text { prepare course } \\
\text { lassignments, handouts }\end{array}$ & 0 & 0.0 & 19 & 5.8 & 4 & 1.2 & 144 & 43.9 & 161 & 49.1 \\
\hline Using ICT in grading exams & 22 & 6.7 & 7 & 2.1 & 14 & 4.3 & 74 & 22.6 & 211 & 64.3 \\
\hline Using ICT in checking results & 8 & 2.4 & 10 & 3.0 & 13 & 4.0 & 86 & 26.2 & 211 & 64.3 \\
\hline
\end{tabular}

\section{Source: Field Data}

Table 2 shows that 134(40.9\%) respondents agreed with the statement that they use ICT in searching instructional materials, $127(38.7 \%)$ teacher trainees strongly agreed with the statement, 32(9.8\%) teacher trainees disagreed with the statement and $28(8.5 \%)$ teacher trainees strongly disagreed with the statement while $7(2.1 \%)$ teacher trainees were undecided on the statement. The study findings showed that majority (79.6\%) of the teacher trainees used ICT in searching teaching and learning materials. This implies that teacher trainees depend on ICT in obtaining new information. This is supported by Twigg (2001) claim that ICTs will change teaching and learning profoundly as computers and internet are used to search for information by teachers on specific subject areas that they are dealing with.

In addition, 164(50.0\%) teacher trainees agreed with the statement that ICT helps in lesson preparation and preparation of notes, 99(30.2\%) teacher trainees agreed with the statement, $39(11.9 \%)$ teacher trainees disagreed with the statement while $26(7.9 \%)$ teacher trainees were undecided on the statement. The Study findings showed that majority $(80.2 \%)$ of teacher 
trainees in teacher training colleges in Rift Valley Region believed that ICT helps in lesson preparation and preparation of notes. This was found to concur with the findings of Hennessy, Onguko, Harrison, Ang'ondi, Namalefe, Naseem, and Wamakote (2010) who found out in their study that ICT helps in lesson preparation and in making teaching materials. This will help improve the quality of secondary education, and also lay the foundations for future use of ICT within primary and secondary classrooms.

Similarly, $117(35.7 \%)$ teacher trainees strongly agreed with the statement that through using teaching media it help (s) clarification of the concepts, and activeness of pupil (s) in learning, $114(34.8 \%)$ teacher trainees agreed with the statement, 69(21.0\%) teacher trainees were undecided on the statement, $25(7.6 \%)$ teacher trainees disagreed with the statement while $3(0.9 \%)$ teacher trainees strongly disagreed with the statement. It emerged from the study findings that majority (70.5\%) of the respondents were of the view that through using teaching media it helps in clarification of the concepts and activeness of pupils in learning. This is supported by Leach and Moon (2000) who argued that ICT had enhanced clarification of abstract concepts and transformation of the understanding of the subject matter.

In addition, 162(49.4\%) teacher trainees strongly agreed with the statement that they search for materials through internet so as to keep themselves updated and increase their confidence and competence in areas of specialization, 132(40.2\%) teacher trainees agreed with the statement, $27(8.2 \%)$ teacher trainees disagreed with the statement while $5(1.5 \%)$ teacher trainees were undecided on the statement. The study findings showed that majority (89.6\%) of the teacher trainees believed that they were getting updated information on their subject areas through the internet. This implies that the internet has recent and updated information on all subject areas and if utilized well keeps one informed on specific subject areas.

Further, it emerged that $189(57.6 \%)$ teacher trainees agreed with the statement that they can use instructional technologies in class activities more effectively day by day, $71(21.6 \%)$ teacher trainees disagreed with the statement, 43(13.1\%) teacher trainees strongly disagreed with the statement and 14(4.3\%) teacher trainees were undecided on the statement while 11(3.4\%) teacher trainees strongly agreed with the statement. The study findings shows that majority $(61.0 \%)$ of the teacher trainees in primary teachers training colleges in Rift Valley Region believed that they can use instructional technologies in class activities more effectively day by day.

On the statement that using graphics makes learning real and enjoyable, $126(38.4 \%)$ teacher trainees agreed with the statement, 125(38.1\%) teacher trainees strongly agreed with the statement, 64(19.5\%) teacher trainees disagreed with the statement while $6(1.8 \%)$ teachertrainees strongly disagreed with the statement. It emerged from the study findings that majority (76.5\%) of the teacher trainees in Colleges in Rift Valley Region believed that using graphics made learning real and enjoyable.

In addition, 152(46.3\%) teacher-trainees agreed with the statement that they get information and research about best practices for teaching by using ICT, 112(34.1\%) teacher trainees strongly agreed with the statement, $23(7.0 \%)$ teacher-trainees disagreed with the statement and $10(3.0 \%)$ strongly disagreed with the statement while $31(9.5 \%)$ teacher-trainees were undecided on the statement. The study findings shows that majority $(70.4 \%)$ of the teachertrainees were of the view that ICT enabled them to get information and researched on best practices for teaching. 
Further, 161(49.1\%) teacher-trainees strongly agreed with the statement that use of ICT makes it easier to prepare course materials (assignments, handouts), $144(43.9 \%)$ teacher trainees agreed with the statement, 19(5.8\%) teacher trainees disagreed with the statement while $4(1.2 \%)$ teacher trainees were undecided on the statement. This shows that majority $(93.0 \%)$ of the teacher trainees believed that use of ICT makes it easier to prepare course materials such as assignments and handouts. This implies that using ICT could make teaching and learning easier since most of the materials needed could be accessed through the internet.

Similarly, 211(64.3\%) teacher-trainees were strongly in agreement with the statement that they used ICT in grading examinations, 74(22.6\%) teacher trainees agreed with the statement while $29(8.8 \%)$ teacher trainees were in disagreement with the statement. It can therefore be argued that majority $(86.9 \%)$ of the teacher trainees used ICT regularly in grading examinations in their schools.

Further, 211(64.3\%) teacher-trainees were strongly in agreement that they use ICT in checking results, 86(26.2\%) teacher-trainees agreed with the statement while 18(5.4\%) teacher trainees were in disagreement with the statement. This implies that majority (90.5\%) of the teacher trainees used ICT in checking results. With the introduction of online results, most of the KCPE and KCSE candidates check their results online similarly most Universities have introduced online systems where students check their examination results.

\section{Teacher-Trainee Perception on Integration of ICT for Instruction}

The second objective of this study was to assess teacher-trainee perception on integration of ICT in teaching and learning in teacher training colleges. To achieve this, the participants were requested to rate questions in five likert scale their agreement on their perception on integration of ICT in teaching and learning process. The results of data analysis are presented in Table 3. 
Table 3: Perception of Teacher-Trainees to Utilization of ICT in Curriculum Instruction

\begin{tabular}{|c|c|c|c|c|c|c|c|c|c|c|}
\hline \multirow[t]{2}{*}{ Statement } & \multicolumn{2}{|c|}{ SD } & \multicolumn{2}{|c|}{$\mathrm{D}$} & \multicolumn{2}{|c|}{ UD } & \multicolumn{2}{|c|}{$\mathrm{A}$} & \multicolumn{2}{|c|}{ SA } \\
\hline & $\mathrm{F}$ & $\%$ & $\mathrm{~F}$ & $\%$ & $\mathrm{~F}$ & $\%$ & $\mathrm{~F}$ & $\%$ & $\mathrm{~F}$ & $\%$ \\
\hline $\begin{array}{l}\text { ICT has impacted quality of } \\
\text { teaching and learning }\end{array}$ & 0 & 0.0 & 16 & 4.9 & 17 & 5.2 & 206 & 62.8 & 89 & 27.1 \\
\hline $\begin{array}{l}\text { ICT can enhance students } \\
\text { participation and feedback to } \\
\text { teacher }\end{array}$ & 3 & .9 & 54 & 16.5 & 35 & 10.7 & 152 & 46.3 & 84 & 25.6 \\
\hline $\begin{array}{l}\text { ICT tends to increase students } \\
\text { learning motivation }\end{array}$ & 0 & 0.0 & 16 & 4.9 & 4 & 1.2 & 198 & 60.4 & 110 & 33.5 \\
\hline \begin{tabular}{lcc} 
ICT can & enhance & \multicolumn{2}{c}{ students' } \\
language & writing skills & e.g. \\
grammar, & spelling & and \\
punctuation & &
\end{tabular} & 21 & 6.4 & 41 & 12.5 & 6 & 1.8 & 124 & 37.8 & 136 & 41.5 \\
\hline $\begin{array}{l}\text { ICT can improve teaching and } \\
\text { learning process }\end{array}$ & 4 & 1.2 & 66 & 20.1 & 13 & 4.0 & 139 & 42.4 & 106 & 32.3 \\
\hline $\begin{array}{l}\text { I feel very confident when it } \\
\text { comes to working with } \\
\text { technology in class }\end{array}$ & 31 & 9.5 & 32 & 9.8 & 33 & 10.1 & 146 & 44.5 & 86 & 26.2 \\
\hline $\begin{array}{llr}\text { I don't use computers as much } \\
\text { as other resources (books, } \\
\text { overhead projectors among } \\
\text { others.) for instructional } \\
\text { purposes }\end{array}$ & 30 & 9.1 & 59 & 18.0 & 23 & 7.0 & 114 & 34.8 & 102 & 31.1 \\
\hline $\begin{array}{l}\text { I believe that tools like e-mail, } \\
\text { forum and chat will make } \\
\text { communication with my } \\
\text { colleagues and students easier }\end{array}$ & 39 & 11.9 & 19 & 5.8 & 17 & 5.2 & 54 & 16.5 & 199 & 60.7 \\
\hline $\begin{array}{l}\text { I think that technology } \\
\text { supported teaching makes } \\
\text { learning more effective }\end{array}$ & 0 & 0.0 & 45 & 13.7 & 11 & 3.4 & 84 & 25.6 & 188 & 57.3 \\
\hline $\begin{array}{l}\text { I think the use of instructional } \\
\text { technologies increases the } \\
\text { quality of courses }\end{array}$ & 0 & 0.0 & 23 & 7.0 & 0 & 0.0 & 134 & 40.9 & 171 & 52.1 \\
\hline $\begin{array}{l}\text { I think that usage of } \\
\text { instructional technologies } \\
\text { makes it easier to prepare } \\
\text { course materials (assignments, } \\
\text { handouts among others) }\end{array}$ & 21 & 6.4 & 30 & 9.1 & 0 & 0.0 & 96 & 29.3 & 181 & 55.2 \\
\hline
\end{tabular}

\section{Source: Field Data}

From the Table 3, it emerged that 206(62.8\%) teacher-trainees agreed with the statement that ICT has impacted on the quality of teaching and learning, 89(27.1\%) teacher-trainees strongly agreed with the statement, 17(5.2\%) teacher trainees were undecided on the statement while $16(4.9 \%)$ teacher trainees disagreed with the statement. The study findings showed that majority (89.9\%) of the teacher-trainees in teacher training colleges in Rift Valley Region believed that ICT had impacted on the quality of teaching and learning. This concurs with Bodys (2005) who reported that many pupils in Scottish schools enriched their learning experience by using ICT in a range of ways across their learning and across the curriculum. In best practice, in both primary and secondary, the use of ICT allowed pupils to be more 
individually and actively involved in the learning process, be more independent in their learning and make more choices about how and what they learned and be able to interact with their learning resources.

Similarly, 152(46.3\%) teacher-trainees agreed with the statement that ICT can enhance students' participation and feedback to teachers, $84(25.6 \%)$ teacher trainees strongly agreed with the statement, 54(16.5\%) teacher trainees disagreed with the statement and 35(10.7\%) teacher-trainees were undecided on the statement while $3(0.9 \%)$ teacher-trainees strongly disagreed with the statement. It emerged from the study findings that majority $(71.9 \%)$ of the teacher trainees believed that ICT can enhance students' participation and feedback to teacher. When ICT is appropriately implemented it can raise quality of education by making learning and teaching an active process connected to real life (Zaman, Shamim \& Clement, 2011).

In addition, 198(60.4\%) teacher-trainees agreed with the statement that ICT tends to increase students learning motivation, $110(33.5 \%)$ teacher trainees strongly agreed with the statement, $16(4.9 \%)$ respondents disagreed with the statement while $4(1.2 \%)$ teacher-trainees were undecided on the statement. The study findings show that a majority (93.9\%) of the teachertrainees believed that ICT tended to increase students learning and motivation. This is supported by Higgins (2004), who argued that ICT improves the teaching and learning process in schools.

In addition, 136(41.5\%) teacher-trainees strongly agreed with the statement that ICT can enhance students' language writing skills such as grammar, spelling and punctuation, $124(37.8 \%)$ teacher-trainees agreed with the statement, $41(12.5 \%)$ teacher-trainees disagreed with the statement, 21(6.4\%) teacher-trainees strongly disagreed with the statement while $6(1.8 \%)$ teacher-trainees were undecided on the statement. The study findings showed that a majority $(79.3 \%)$ of the teacher-trainees were of the opinion that ICT can enhance students' language writing skills such as grammar, spelling and punctuation. This is supported by Leakey (2011) who pointed out that implementation of ICT enhances students' language skills and therefore increasing their performance in their specific fields of study.

Further,139(42.4\%) teacher-trainees agreed with the statement that ICT can improve teaching and learning process, 106(32.3\%) teacher-trainees strongly agreed with the statement, $66(20.1 \%)$ teacher-trainees disagreed with the statement while $13(4.0 \%)$ teacher trainees were undecided on the statement. It can therefore be shown that a majority $(74.7 \%)$ of the teacher trainees believed that ICT can improve teaching and learning process. This is supported by UNDP (2001) report which indicated that in across a range of educational applications, ICT is being harnessed to improve the efficiency, accessibility and quality of the learning process in developing countries.

Similarly, $146(44.5 \%)$ teacher-trainees agreed with the statement that they felt very confident when it comes to working with technology in class; 86(26.2\%) teacher-trainees strongly agreed with the statement, 33(10.1\%) teacher-trainees were undecided on the statement while $63(19.3 \%)$ teacher-trainees were in disagreement with the statement. This shows that a majority $(70.7 \%)$ of the teacher trainees were very confident while using ICT materials in class.

On the statement that “I don't use computers as much as other resources (books, overhead projectors among others) for instructional purposes", 114(34.8\%) teacher-trainees agreed with the statement, 102(31.1\%) teacher-trainees strongly agreed with the statement, $59(18.0 \%)$ teacher-trainees disagreed with the statement, 30(9.1\%) teacher trainees strongly 
disagreed with the statement while 23(7.0\%) teacher-trainees were undecided on the statement. The study findings suggested that a majority $(65.9 \%)$ of the teacher-trainees did not use computers as much as other resources (books, overhead projectors) for instructional purposes. This implies that teacher-trainees do not have access to computer equipments for use in the teaching and learning process. Emans (2002) noted that a success factor for ICT in education is the availability of good equipment. It is important that both pupils and teachers have regular access to up-to-date ICT equipment. Nowadays, in many schools there are computer labs. But having enough equipment available might involve designing entire new school architecture, with computer labs. This finding concurs with findings of Becta, (2002) and Waema, (2002).

Further, 199(60.7\%) teacher-trainees strongly agreed with the statement that "I believe that tools like e-mail, forum and chat will make communication with my colleagues and students easier", 54(16.5\%) teacher-trainees agreed with the statement, 39(11.9\%) teacher trainees strongly disagreed with the statement while 19(5.8\%) teacher-trainees disagreed with the statement. The study findings showed that a majority $(77.2 \%)$ of the teacher-trainees believed that tools like e-mail, forum and chat will make communication with their colleagues easier.

Notwithstanding, 188(57.3\%) teacher-trainees strongly agreed with the statement that technology supported teaching makes learning more effective, 84(25.6\%) teacher-trainees agreed with the statement, 45(13.7\%) teacher-trainees disagreed with the statement while $11(3.4 \%)$ teacher-trainees were undecided on the statement. The study findings suggested that a majority (82.9\%) of the teacher-trainees believed that technology supported teaching makes learning more effective.

Further, 171(52.1\%) teacher-trainees strongly agreed that the use of instructional technologies increases the quality of courses, $134(40.9 \%)$ teacher-trainees agreed with the statement while $23(7.0 \%)$ teacher-trainees were in disagreement with the statement. This shows that a majority (93.0\%) of the teacher-trainees in teacher training colleges in Rift Valley region were of the view that the use of instructional technologies increases the quality of courses.

Similarly, 181(55.2\%) teacher-trainees strongly agreed with the statement that usage of instructional technologies makes it easier to prepare course materials (assignments, handouts among others) 96(29.3\%) teacher trainees agreed with the statement, $30(9.1 \%)$ teachertrainees disagreed with the statement while 21(6.4\%) teacher-trainees strongly disagreed with the statement. The study findings suggested that a majority $(84.5 \%)$ of the teachertrainees believed that usage of instructional technologies makes it easier to prepare course materials (assignments and handouts).

\section{Teacher Trainees' Use of E-Materials during Instruction Process}

The third objective of this study was to investigate the teacher trainees' use of e-materials during learning process. To achieve this, the respondents were requested to rate their level of agreement on five likert scale questions on teachers-trainee use of e-materials during learning process. The results are presented in Table 4. 
Jepchirchir, K. J., Kipsaina, K. J., \& Boit, K. M. (2017) Teacher-Trainee Preparedness on Integration of ICT for Instruction in Selected Public Teacher Training Colleges in North Rift, Kenya. Advances in Social Sciences Research Journal, 4(5) 29-43

Table 4: Teacher Trainees' Use of E-Materials During Instruction Process

\begin{tabular}{|l|r|r|r|r|r|c|r|r|}
\hline \multirow{2}{*}{ Statement } & \multicolumn{2}{|c|}{ Never } & \multicolumn{2}{c|}{ Occassionally } & \multicolumn{2}{c|}{ Frequently } & \multicolumn{2}{c|}{ Almost Always } \\
\cline { 2 - 9 } & \multicolumn{1}{|c|}{$\mathrm{F}$} & \multicolumn{1}{c|}{$\%$} & \multicolumn{1}{c|}{$\mathrm{F}$} & \multicolumn{1}{c|}{$\%$} & \multicolumn{1}{c|}{$\mathrm{F}$} & \multicolumn{1}{c|}{$\%$} & \multicolumn{1}{c|}{$\mathrm{F}$} & \multicolumn{1}{c|}{$\%$} \\
\hline Use of ICT applications & 46 & 14.0 & 133 & 40.5 & 82 & 25.0 & 67 & 20.4 \\
\hline Presentation tools & 46 & 14.0 & 90 & 27.4 & 113 & 34.5 & 79 & 24.1 \\
\hline Online demonstrations & 58 & 17.7 & 73 & 22.3 & 137 & 41.8 & 60 & 18.3 \\
\hline Using word processing & 25 & 7.6 & 96 & 29.3 & 104 & 31.7 & 103 & 31.4 \\
\hline Graphical visualization tools & 0 & 0.0 & 173 & 52.7 & 68 & 20.7 & 87 & 26.5 \\
\hline Spread sheets & 44 & 13.4 & 126 & 38.4 & 72 & 22.0 & 86 & 26.2 \\
\hline Internet browsing & 36 & 11.0 & 170 & 51.8 & 107 & 32.6 & 15 & 4.6 \\
\hline
\end{tabular}

\section{Source: Field Data, 2014}

Table 4 shows that $133(40.5 \%)$ teacher trainees occasionally used ICT applications during learning process, $82(25.0 \%)$ teacher-trainees frequently used ICT applications during learning process, 67(20.4\%) teacher-trainees almost always used ICT applications during learning while 46(14.0\%) teacher-trainees never used ICT applications during learning. The study findings showed that most (40.5\%) of the teacher-trainees occasionally uses ICT applications during learning process. This implies that ICT materials may not be adequate in teachers' training colleges for all the teacher-trainees. Emans (2002) noted that a success factor for ICT in education is the availability of good equipment. It is important that both students and teachers have regular access to up-to-date ICT equipment. Many schools, colleges and universities have computer laboratories. However, these equipments in the labs may not be adequate for all students as cited by Becta (2003) which was found to be in agreement with the finding of this study.

Similarly, $113(34.5 \%)$ teacher-trainees frequently used presentation tools in learning, $90(27.4 \%)$ teacher trainees occasionally used presentation tools for learning and $79(24.1 \%)$ respondents almost always use presentation tools for learning while $46(14.0 \%)$ teachertrainees never use presentation tools during learning process. It seems therefore that majority of the teacher trainees used presentation tools for learning however, most (34.5\%) of them used these tools frequently.

Further, 137(41.8\%) teacher-trainees frequently used online demonstrations for learning, 73(22.3\%) teacher-trainees occasionally used online demonstrations for learning and $60(18.3 \%)$ teacher-trainees almost always used online demonstrations for learning while $58(17.7 \%)$ teacher-trainees never used online demonstrations for learning. It can therefore be shown that most (41.8\%) of the teacher-trainees in teachers' training colleges in Rift Valley Region frequently used online demonstrations for learning.

In addition, 104(31.7\%) teacher-trainees frequently used word processing for learning, $103(31.4 \%)$ teacher-trainees almost always used word processing for learning and 96(29.3\%) teacher trainees occasionally used word processing for learning while 25(7.6\%) teachertrainees never used word processing for learning. This shows that a majority of the teachertrainees frequently or almost always use word processing for learning. This shows that word processing is the most commonly used e-material for learning.

Similarly, $173(52.7 \%)$ teacher-trainees cited that they occasionally used graphical visualization tools for learning, $87(26.5 \%)$ teacher trainees reported that they used graphical visualization tools for learning almost always while $68(20.7 \%)$ teacher-trainees cited that they used graphical visualization tools for learning frequently. This shows that most of the teacher 
trainees used visualization tools for learning occasionally. Furthermore $126(38.4 \%)$ teachertrainees indicated that they used spread sheets occasionally for learning, 86(24.7) teachertrainees reported that they almost always used spread sheets for learning while $72(22.0 \%)$ teacher-trainees cited that they frequently used spread sheets for learning. It emerged therefore that most of the teacher-trainees occasionally used spread sheets during the learning process.

However, it further emerged that $170(51.8 \%)$ teacher-trainees occasionally used internet browsing for learning, 107(32.6\%) teacher-trainees reported that they frequently used internet browsing for learning and 36(11.0\%) teacher-trainees reported that they had never used internet browsing as a tool for learning while 15(4.6\%) teacher-trainees indicated that they almost always used internet browsing for learning. It therefore emerged that internet browsing was commonly used by teacher-trainees for learning. However, most (51.8\%) of the teacher-trainees used it occasionally for learning.

\section{Conclusions}

\section{CONCLUSIONS AND RECOMMENDATIONS}

The following conclusions were made based on the study findings;

1. Teacher trainees used ICT in searching for teaching and learning materials, preparation of lessons, preparation of notes, clarification of the concepts, preparation of course materials such as assignments and handouts and grading examinations. ICT had effect on the quality of teaching and learning and increased students learning and motivation. However, teacher-trainees did not have access to computer equipments for use in the teaching and learning process.

2. Teacher trainees' occasionally used e-materials during learning process. However, these materials were found to be inadequate for all student-teachers. The most commonly used e-materials were word-processing, visualization tools, spread sheets and internet browsing.

3. Teacher-trainees had a positive perception towards use of e-materials in the teaching and learning process. The use of ICT allowed active teaching and learning process, interaction of learners with e-materials and increased students learning and motivation.

\section{Recommendations}

Based on these findings the following recommendations were made:

1. Teacher trainees' use of ICT materials has enhanced teaching and learning process and therefore it has made preparation of teaching and learning materials easier. Teacher trainees therefore need to have basic skills in computer application by undergoing ICT training for easier use of these materials. Teacher-trainees did not have access to computer equipments for use in the teaching and learning process. Therefore, computer equipments need to be availed to all students in order to enhance its use during learning process that will empower them with skills and content to use them in actual teaching practice. TTCs should ensure that they equip computer labs with adequate facilities and gives students' access to use the lab.

2. The policy and decision makers in Government should implement those policies and decisions that favour literacy in the ICTs particularly provision of infrastructure and ICT components in schools. The County Director and commission of Education should take up the development of ICT infrastructure in learning institutions as one of the plan activity in their physical plan.

3. ICT has to be integrated into the teacher education programmes to ensure their preparedness to adopt its use at the classroom level. A standard planned ICT practical course curriculum of one sit-in exams for teacher education programmes should be 
developed and maintained to ensure that graduates of teacher training programme are professionally competent on completion of the programme.

4. Teachers should be encouraged to develop more confidence in their individual ability at becoming computer literate teachers in order to buttress the efforts of the government and educators' ability to provide ICT learning environment. Thus the government as the pace setter needs to work hard at finding solutions to the problems that pose these challenges. Their commitment and overall involvement dictate the performance of the educators and subsequently an improvement in the learning environment. This will further enhance trainees' preparedness for integration of ICT in teacher education programmes that will subsequently realize the integration of ICT in teaching and learning process upon their practicing.

\section{References}

Anderson, J. \& Weert, V, T. (2002). Information and Communication Technology in Education: A Curriculum for schools and Programme of Teacher Development. Division of Higher Education. UNESCO.

Becta (2002) Barriers to the use of ICT in teaching from http://

www.becta.org.uk/page_documents/research/wtrs_barriersinteach.pdf.

Bodys, W. (2005). The integration of information and communications technology in Scottish schools: An interim report by HM Inspectors of Education.

Creswell, L. (2009). Research Design: Qualitative, Quantitative and Mixed Methods Approaches: 3rd Edition. University of Nebraska-Lincoln: SAGE Publication, inc.

Dawes, L (2001). What stops teachers using new technology? In M. Leask (Ed.). Issues in Teaching using ICT. London Routledge.

Emans, B.(2002) Integration of ICT in Education Guidelines for school Directors and policy makers - IPAMONG OTHERSCO Consortium.

Johnson, B., \& Onwuegbuzie, A. (2006). Mixed methods research: A research paradigm whose time has come. Educational Researcher, 33(7), 14-26.

Kothari C.K (2004). Research Methodology: Methods and Techniques 2005. KWTS Publishers

Kothari, C. R. (2008) Research Methodology. Methods and Techniques, Second Revised Edition. New Age International Publishers, New Delhi.

Leach, J. \& Moon, B. (2000). 'Pedagogy, information and technology and teachers' professional knowledge', The Curriculum Journal, vol. 11, no. 3, pp. 385-404.

Leakey, J. (2011). Evaluating Computer Assisted Language Learning: an integrated approach to effectiveness research in CALL. Bern: Peter Lang.

Lin, J. C., \& Lu, H. (2000). Towards an understanding of the behavioral intention to use a Web Site. International Journal of Information Management, 20, 197-208.

Mikre, F. (2011). The Roles of Information Communication Technologies in Education Review Article with Emphasis to the Computer and Internet. Ethiop. J. Educ. \& Sc. Vol. 6 No 2

Mwalongo , A. (2011). Teachers' perceptions about ICT for teaching, professional development, administration and personal use. International Journal of Education and Development using Information and Communication Technology (IJEDICT), 2011, Vol. 7, Issue 3, pp. 36-49.

Sife, A.S., Lwoga, E.T. \& Sanga, C. (2007). New technologies for teaching and learning: Challenges for higher learning institutions in developing countries. International Journal of Education and Development using Information and Communication Technology (IJEDICT), 3, (2), 57-67.

Teddlie, C. \& Tashakkori, A. (2009). Foundations of Mixed Methods Research. Thousand Oaks, CA: Sage Publications.

Tinio, V. L. (2003). ICT in Education. E-Primers for the Information Economy, Society and Polity. Manila: E-ASEAN Task Forse/UNDP-APDIP. Retrieved from http: www. apdip. Net /publications /iespprimers/ ICTinEducation.pdf. 
Twigg, C. A. (2001) Innovations in Online Learning: Moving Beyond no Significant Difference. The Pew Learning and Technology Program. [2003.10.08]. Accessible from http://www.center.rpi.edu

Voogt, J. (2003). Consequences of ICT for aims, contents, processes, and environments of learning. In J. van den Akker, W. Kuiper \& U. Hameyer (Eds.), Curriculum landscapes and trends (pp 217 - 236). Dordrecht: Kluwer Academic Publishers.

Waema, T. M. (2002) ICT Human Resource Development in Africa: Challenges and Strategies http://www.atpsnet. org/content/files/ documents/ Special\% 20Paper\% 20 Series\%201 0.pdf

Zaman, M, Shamim, R, \& Clement K (2011).Trends and issues to integrate ICT in teaching learning for the future world of education. International Journal of Engineering \& Technology 11(3) 114-119. 